\title{
Modelling boreal lake catchment response to anthropogenic acid deposition
}

\author{
Colin J. WHITFIELD*, Julian AHERNE, B. Jack COSBY ${ }^{1)}$ and Shaun A. WATMOUGH \\ Environmental and Resource Studies, Trent University, 1600 West Bank Dr., Peterborough, ON K9J 7B8, Canada \\ ${ }^{1)}$ Department of Environmental Science, University of Virginia, Clark Hall, 291 McCormick Rd., Charlottesville, VA 22904, USA \\ *e-mail corresponding author: cwhitfield@trentu.ca
}

\begin{abstract}
A dynamic hydrogeochemical model of water acidification (MAGIC: Model of Acidification of Groundwater in Catchments) was applied to two catchments with contrasting hydrological influences in the Athabasca Oil Sands Region of Alberta to predict catchment response to elevated levels of acidic deposition. Key processes that determine catchment response to atmospheric deposition, including groundwater base cation inputs and retention of sulphur (S) in peatland complexes were parameterized in the model. Although deposition of $S$ and nitrogen $(N)$ in the region has increased over the last 40 years, levels are low at the study sites relative to impacted areas of eastern North America. Model forecasts for the period 2005-2100 were run under constant 2005 deposition levels (base case) and at acid deposition double this level. Simulated past and future soil base saturation was constant over the course of the 200 year (1900-2100) modelled period. At the lake with high charge balance acid neutralizing capacity $\left(A N C_{C B}\right)$, where large base cation sources dominate lake chemistry, little change in surface water chemistry was predicted under either forecast scenario. Under the double acid forecast scenario at the low $A N C_{C B}$ lake, simulated lake $A N C_{C B}$ decreased in response to elevated $S$ deposition, but the magnitude of decrease was comparable to the range in observational data. The simulations suggest limited risk of acidification, primarily due to $S$ retention in the catchments, but the potential for drought-induced episodic depression of $A N C_{C B}$ may be important on this landscape.
\end{abstract}

Key words: Athabasca Oil Sands, atmospheric deposition, MAGIC, surface water acidification, Canada

\section{INTRODUCTION}

Since the 1960s, mining of oil sands deposits located in northern Alberta, Canada has proliferated. The largest of these deposits, totalling approximately 130 billion barrels of recoverable oil, is located in the Athabasca Oil Sands Region (AOSR) encompassing the city of Fort McMurray (Timilsina et al. 2005). The oil in these deposits is in the form of bitumen, heavy carbon-rich oil that requires extensive processing for conversion to synthetic crude oil. As a consequence of bitumen extraction and processing, atmospheric emissions of sulphur $(\mathrm{S})$ and nitrogen $(\mathrm{N})$ in the region have risen dramatically. Large areas of the region have been identified as acid-sensitive owing to low alkalinity and $\mathrm{pH}$ of lakes (Palmer \& Trew 1987) and poorly weatherable soils with low acid neutralizing capacity (Holowaychuk \& Fessenden 1987). Furthermore, recent applications of steady-state critical load models have identified exceedance of the critical load of acidity ( $\mathrm{S}$ and $\mathrm{N}$ ) for both lakes (S: Bennett et al. 2008) and upland forest soils (S and N: Carou et al. 2008; Whitfield et al. 2010, this issue); however it is unknown when exceedance of critical chemical limits may occur. The level of S deposition in the AOSR is currently lower than high deposition regions in central and eastern Canada, but production rates are expected to increase dramatically over the next 10 years (Timilsina et al. 2005). With the potential for $\mathrm{S}$ and $\mathrm{N}$ emissions to increase into the future, there are concerns over possible acidification impacts on the surrounding environment. The effects-based emissions control policy for the region is dependent on model predictions of the time scale over which changes in soil and surface water chemistry are expected to occur.

Unlike steady-state models that estimate the (endpoint) condition of the system at equilibrium, dynamic acidification models can be used to simulate changes through time and to identify when an ecosystem will reach a critical chemical limit (the time-to-effect). The Model of Acidification of Groundwater in Catchments (MAGIC: Cosby et al. 1985) has been one of the most widely used acidification models owing to its ability to reconstruct the history of acidification and to simulate future change in soil and stream chemistry (Cosby \& Wright 1998). It has been applied to a wide range of sites across many countries in Europe, including alpine catchments (Kopacek et al. 2004), boreal catchments (Aherne et al. 2008), and catchments with significant areas of organic soils (Helliwell et al. 1998). The model has been used extensively in Canada (e.g., Aherne et al. 2003; Clair et al. 2003; Larssen et al. 2003; Whitfield et al. 2007), it has moderate data requirements, and its versatility has been demonstrated repeatedly. Nonetheless, application of MAGIC to lake catchments in the AOSR poses a new challenge, as these catchments are atypical of catchments where MAGIC was developed and has been used previously. Specifically, catchments in the AOSR: (1) are difficult to delineate as they have low topographic relief; (2) have complex hydrology with varying groundwater influences and a range in character 
from evaporative to throughflow; and (3) are typically dominated by large fen complexes.

The objective of this study was to apply MAGIC at two boreal lake catchments in the AOSR in order to predict past and future response of soil and surface water chemistry to changes in atmospheric deposition of $\mathrm{S}$ and $\mathrm{N}$. This was the first application of the model to catchments in this region and focussed on the only two intensively studied catchments in the region; these catchments have the most complete understanding of hydrology, and a detailed inventory of soil and surface water data. The study catchments are dominated by large fens, but exhibit contrasting hydrologic behaviour and differ widely in their acid-sensitivity. Because this represents the first catchment-based application of MAGIC in the region, the paper focuses heavily on the methods used to parameterize and calibrate the model in this environment.

\section{METHODS}

\subsection{Study area and site descriptions}

The continental boreal climate of the AOSR favours the establishment of peatlands, with average daily temperatures ranging from $-18.8{ }^{\circ} \mathrm{C}$ in January to $16.8{ }^{\circ} \mathrm{C}$ in July (Environment Canada 2009). As such, extensive [up to $50 \%$ of the landscape (D.H. Vitt, pers. comm.)] areas of the Boreal Plains ecozone in northern Alberta are covered by peatlands. Many lake catchments in the region feature these muskeg peatlands, composed primarily of fens (with smaller areas of bog), where Sphagnum moss, sedges, and sparse growth of scrubby trees (e.g., black spruce (Picea mariana), and tamarack (Larix laricina) are typical. These organic soils have a large influence on surface water chemistry (Prepas et al. 2001), thus lakes in the region tend to be dystrophic. Upland forests on sandy, well-drained brunisolic soil deposits (Agriculture and Agri-Food Canada 1998) are also common to the region, but are less spatially extensive than peatlands. These forests are dominated by jack pine (Pinus banksiana), with balsam fir (Abies balsamea) and trembling aspen (Populus tremuloides) also present. The region is relatively arid, with annual precipitation for the region averaging approximately $0.53 \mathrm{~m}$ (Mesinger et al. 2006).

Both study sites are remote headwater catchments, located approximately $60 \mathrm{~km}$ northeast (NE07: $57.13^{\circ}$ $\mathrm{N}, 110.89^{\circ} \mathrm{W}$ ) and $50 \mathrm{~km}$ south (SM08: $56.21^{\circ} \mathrm{N}$, $\left.111.19^{\circ} \mathrm{W}\right)$ of the town of Fort McMurray. At both catchments, the area covered by peatlands is large (Tab. 1) with comparatively small upland areas covered by mature, even-aged jack pine dominated stands. NE07 is the smaller of the two catchments and has a low relative lake area of only $2.2 \%$ compared with $20.3 \%$ for SM08 (Tab. 1). Catchment boundaries and landscape areas (Tab. 1) were determined using LIDAR (light detection and ranging) and digital elevation models (J.J. Gibson, pers. comm.). The study sites exhibit contrasting hydrologic behaviour, with NE07 more characteristic of a throughflow system and SM08 subject to greater evaporation as evidenced by greater isotopic enrichment $\left({ }^{18} \mathrm{O}\right.$ and ${ }^{2} \mathrm{H}$ : Bennett et al. 2008). The lakes are both shallow and well mixed, with low pH (NE07: 5.2, SM08: 5.1) and Gran alkalinity (NE07: $52.6 \mu \mathrm{eq} \mathrm{L} \mathrm{L}^{-1}$, SM08: $-2.1 \mu \mathrm{eq} \mathrm{L}^{-1}$ ) and high dissolved organic carbon (DOC) concentrations (NE07: $31.0 \mathrm{mg} \mathrm{L}^{-1}$, SM08: 17.6 $\mathrm{mg} \mathrm{L}^{-1}$ ), but range considerably in acid-sensitivity, with charge balance acid neutralizing capacity $\left(\mathrm{ANC}_{\mathrm{CB}}\right)$ of 261 and $85 \mu \mathrm{eq} \mathrm{L}{ }^{-1}$ at NE07 and SM08, respectively.

Tab. 1. Physical characteristics and total deposition (2005) for the two study catchments.

\begin{tabular}{|c|c|c|c|}
\hline Parameter & Units & NE07 & SM08 \\
\hline Precipitation & $\mathrm{m}$ & 0.54 & 0.55 \\
\hline Runoff & $\mathrm{m}$ & 0.16 & 0.12 \\
\hline Catchment Area & $\mathrm{km}^{2}$ & 5.1 & 9.6 \\
\hline Lake Area & $\%$ & 2.2 & 20.3 \\
\hline Peatland Area & $\%$ & 77.5 & 67.5 \\
\hline Retention Time & $\mathrm{y}$ & 0.14 & 1.57 \\
\hline S & meq $\mathrm{m}^{-2}$ & 24.9 & 25.2 \\
\hline $\mathrm{N}$ & meq $\mathrm{m}^{-2}$ & 11.8 & 14.9 \\
\hline $\mathrm{Cl}^{-}$ & $\mathrm{meq} \mathrm{m}^{-2}$ & 1.4 & 1.3 \\
\hline $\mathrm{Ca}^{2+}$ & meq $\mathrm{m}^{-2}$ & 11.3 & 16.4 \\
\hline $\mathrm{Mg}^{2+}$ & meq $\mathrm{m}^{-2}$ & 2.1 & 2.3 \\
\hline $\mathrm{Na}^{+}$ & meq $\mathrm{m}^{-2}$ & 2.7 & 2.6 \\
\hline $\mathrm{K}^{+}$ & meq $\mathrm{m}^{-2}$ & 0.6 & 0.6 \\
\hline
\end{tabular}

\subsection{Model description}

MAGIC (Cosby et al. 1985) is a process-oriented lumped parameter model of intermediate complexity, and has undergone numerous changes since inception (Cosby et al. 2001), notably the addition of a wetland compartment. MAGIC was developed for the purpose of quantifying the long-term catchment scale hydrogeochemical response of soil and surface water to acidic deposition. The model is used to simulate average annual or monthly soil solution and surface water concentrations for major ions and $\mathrm{pH}$, as well as soil exchangeable calcium $\left(\mathrm{Ca}^{2+}\right)$, magnesium $\left(\mathrm{Mg}^{2+}\right)$, sodium $\left(\mathrm{Na}^{+}\right)$and potassium $\left(\mathrm{K}^{+}\right)$. Physical and chemical data detailing soils and surface waters are used in the model to represent a catchment with a surface water compartment (lake or stream) and up to two uniform soil compartments and a wetland compartment. The most recent version of the model (7.77ext) was used in this study.

The model includes short-term processes described by equilibrium reactions that regulate ionic balance, and long-term input-output processes that control the catchment mass balance. The equilibrium equations are represented by inorganic aluminium reactions for surface and soil water, cation exchange reactions, and inorganic carbon equations that describe the chemical change that occurs as soil water exits to the surface. Weathering of minerals, exchange of base cations and aluminium by soils, anion retention (adsorption), buffering of soil solution $\mathrm{pH}$ by weak organic and inorganic acids and 
biologically mediated uptake of cations and anions are among the processes included in the soil compartment. Processes in the wetland compartment are similar, but sulphate $\left(\mathrm{SO}_{4}{ }^{2-}\right)$ retention can be described using $\mathrm{S}$ reduction characteristics. A triprotic $\mathrm{pH}$ model is included for modelling soil and surface water organic acidity. Rates of change for each ion are calculated through the mass balance equations, which collectively describe the input-output relationships for base cations and strong acid anions in soil water and surface water. MAGIC is calibrated using observed soil exchangeable base cation fractions (eBC) and the long-term average annual lake water chemistry (e.g., target values for model simulations in the calibration year).

\subsection{Site data}

At each catchment, multiple pits (NE07: 9, SM08: 6) were sampled in representative mineral soil deposits in 2005. Soil pits were approximately $1 \mathrm{~m}$ in diameter and extended to the $\mathrm{C}$ horizon (approximate depth of $1 \mathrm{~m}$ ). The litter, fibric, humic (LFH) layer was sampled using a quadrate, and a composite sample for each soil horizon was collected from multiple faces of each soil pit. The depth of all soil horizons was recorded in the field. Peat was collected from the acrotelm across each fen complex at $100 \mathrm{~m}$ intervals $(\mathrm{n}=66$; see Whitfield 2009). All soil samples were stored in sealed plastic bags for transport to the laboratory, where they were air dried at $20^{\circ} \mathrm{C}$ and sieved to $2 \mathrm{~mm}$ (mineral horizons) or ground to a finer particle size prior to analysis (LFH and peat). The analysis of eBC and cation exchange capacity (CEC) of mineral soils and LFH using a two-step salt extraction $\left(\mathrm{NH}_{4} \mathrm{Cl}, \mathrm{NaCl}\right)$ followed Whitfield et al. (2006a). Base cation concentrations were analysed using flame atomic absorption spectrometry ( $\operatorname{Varian}^{\mathrm{TM}}$ 240FS) and ammonium $\left(\mathrm{NH}_{4}{ }^{+}\right)$concentrations used to quantify CEC were measured by colourimetry (SEAL ${ }^{\mathrm{TM}}$ AutoAnalyser 3 Quattro). Bulk density (BD) for the LFH horizon was calculated from the dry mass of the soil and the volume of the sample, while for the mineral horizons $\mathrm{BD}$ was calculated from loss on ignition (LOI) using a pedotransfer function (De Vos et al. 2005). Mineral soils from the A and B-horizons were analysed for mineralogy by X-ray diffraction using a Siemens ${ }^{\mathrm{TM}}$ (Bruker) D5000 Bragg-Brentano diffractometer, and for particle size to determine the fractions of sand, silt and clay using a Horiba ${ }^{\mathrm{TM}}$ Partica LA-950; these data served as inputs to the PROFILE model (Warfinge \& Sverdrup 1992) used to estimate the weathering rates utilized for MAGIC calibration. In addition, at each catchment mineral soils were instrumented with soil probes to measure daily soil temperature and moisture values; average annual values were used as model inputs.

Surface water chemistry for the study lakes has been collected since 2002 by Alberta Environment, with a sampling frequency usually four times per year during the open water season (typically April/May, June/July,
Aug/Sept, and October). Lake water samples were collected at mid-lake from a depth of approximately $20 \mathrm{~cm}$ and stored in HDPE bottles. Electrical conductivity and $\mathrm{pH}$ of the lake were measured during sample collection. Water samples were shipped on ice to the University of Alberta where they were analysed for Gran alkalinity, $\mathrm{NH}_{4}{ }^{+}$, nitrate $\left(\mathrm{NO}_{3}{ }^{-}\right)$, DOC, dissolved inorganic carbon (DIC), chloride $\left(\mathrm{Cl}^{-}\right), \mathrm{SO}_{4}{ }^{2-}, \mathrm{Na}^{+}, \mathrm{K}^{+}, \mathrm{Ca}^{2+}$ and $\mathrm{Mg}^{2+}$. Soil water was collected from the B-horizon during the summer of 2006 using stainless steel tension lysimeters and analysed for $\mathrm{SO}_{4}{ }^{2-}$ using ion chromatography (Dionex ${ }^{\mathrm{TM}} 6000$ ) and for $\mathrm{pH}$ and Gran alkalinity (PCTitration Plus ${ }^{\mathrm{TM}}$ ).

\subsection{Deposition}

Bulk deposition of $\mathrm{NH}_{4}{ }^{+}, \mathrm{NO}_{3}{ }^{-}, \mathrm{SO}_{4}{ }^{2-}, \mathrm{Ca}^{2+}, \mathrm{Mg}^{2+}$ was measured at the study catchments using ion exchange resin (IER) columns during the period 20052008 (R.K. Wieder, pers. comm.). Fenn \& Poth (2004) described the advantages of using IER columns to measure deposition at remote sites and have demonstrated that this approach provides bulk deposition estimates comparable to conventional methods (e.g., rain gauges). Total deposition of $\mathrm{N}, \mathrm{S}, \mathrm{Ca}^{2+}$ and $\mathrm{Mg}^{2+}$ (Tab. 1) was estimated by converting bulk deposition to wet deposition using element-specific observed bulk to wet deposition ratios, with wet deposition estimates converted to total using modelled wet to total deposition ratios for the region (Vet \& Shaw 2004). Deposition measured with IER columns represented approximately $50 \%$ of calculated total deposition, with $\mathrm{N}$ deposition composed of approximately equal amounts $\mathrm{NH}_{4}{ }^{+}$and $\mathrm{NO}_{3}{ }^{-}$. Chloride, $\mathrm{Na}^{+}$, and $\mathrm{K}^{+}$represent minor components of total deposition, and were assumed to exhibit negligible temporal change; regional maps of wet and dry deposition for the period 1994-1998 at a resolution of $35 \mathrm{~km} \times 35 \mathrm{~km}$ (Vet \& Shaw 2004) were used to estimate current deposition (Tab. 1).

\subsubsection{Scenarios}

Hindcast deposition sequences for the period 19002005 were created for $\mathrm{SO}_{4}^{2-}, \mathrm{N}^{2} \mathrm{NO}_{3}^{-}$and $\mathrm{NH}_{4}^{+}$followed the same sequence as individualized inventories were not available) and base cations. Background (1900) deposition levels were estimated from measurements at remote deposition monitoring stations in Snare Rapids, NWT ( $\mathrm{SO}_{4}{ }^{2-}$ ) and Cree Lake, SK (base cations), and from trends in global emissions of $\mathrm{N}$ (Galloway 1995). Cree Lake is located within the same ecozone as the study sites and is expected to most accurately reflect background base cation deposition while Snare Rapids is at greater distance from development and anticipated to provide the best estimate of historical $\mathrm{SO}_{4}{ }^{2-}$ deposition. The sequences for $\mathrm{SO}_{4}{ }^{2-}$ and $\mathrm{N}$ were constructed from a regional emissions inventory for the period 1970-2005 (Golder 2003); emissions were assumed to remain close to background levels during the early part 


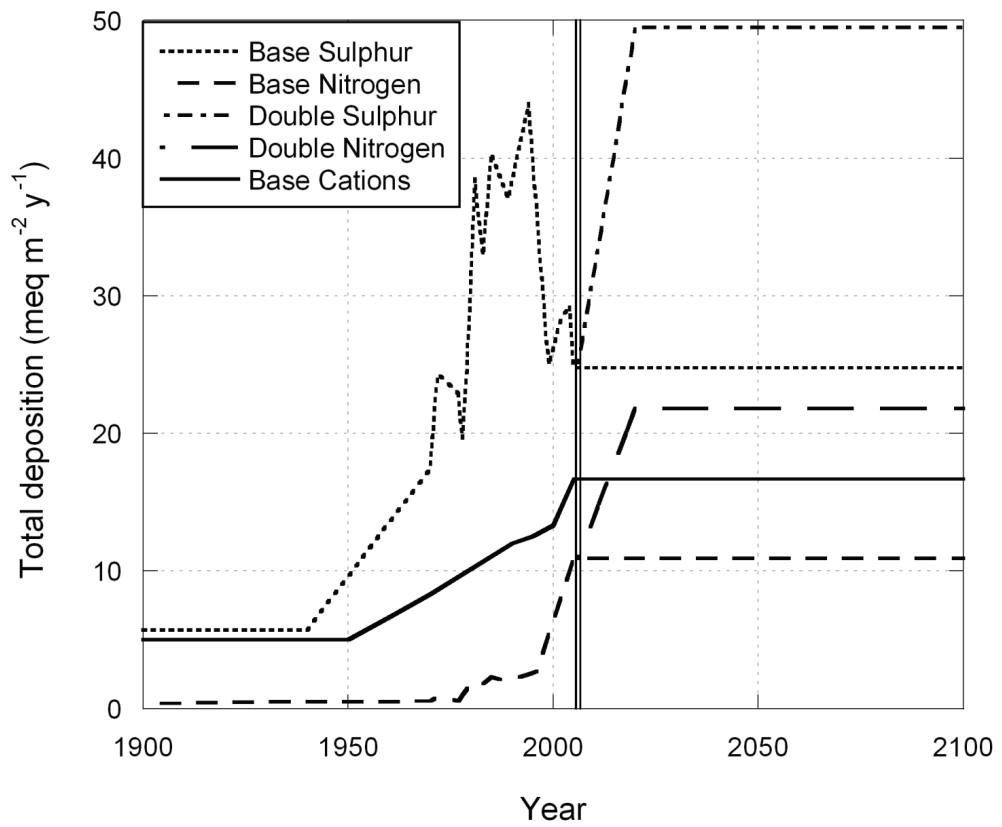

Fig. 1. Atmospheric deposition of sulphur $(\mathrm{S})$, nitrogen $(\mathrm{N})$ and base cations for hindcast (base case) and forecast (base case, double acid) scenarios at NE07. Calibration year is indicated by double vertical line. Deposition patterns at SM08 are identical to those shown here, and 2005 deposition for SM08 is provided in table 1.

of the century with large increases occurring with commencement of oil sands operations (1960s) (Fig. 1). Base cation deposition has been shown to follow changes in $\mathrm{SO}_{4}{ }^{2-}$ deposition level in eastern North America (Hedin et al. 1994) and $\mathrm{Ca}^{2+}$ deposition (the dominant base cation in deposition) is highly correlated with $\mathrm{SO}_{4}{ }^{2-}$ at the Fort McMurray meteorological station $(r=0.84)$; extraction of bitumen in the AOSR involves large-scale disturbance of the ground surface (e.g., open pit mining) which stimulates airborne dust. Consequently, the hindcast sequence for base cation deposition used herein is based on both production levels and $\mathrm{S}$ emissions inventories (Fig. 1). Future $\mathrm{S}$ emission levels remain uncertain; a threefold increase in oil production from 2005 levels is projected by 2015 (from one to three million barrels per day: Timilsina et al. 2005) and elevated $\mathrm{SO}_{4}{ }^{2-}$ deposition is probable. Two scenarios (base case, double acid) are used in the current study for model forecasts through to the year 2100 (Fig. 1). The base case forecast scenario projects deposition of $\mathrm{S}, \mathrm{N}$, and base cations at present (2005) levels for the period 2006-2100. Under the double acid forecast scenario, $\mathrm{SO}_{4}{ }^{2-}$ and $\mathrm{N}$ deposition increase two-fold between 2006 and 2020 and remain unchanged thereafter, while base cation deposition remains constant at 2005 levels for the duration of the forecast. The assumptions underpinning the double acid scenario are that increases in $\mathrm{SO}_{4}{ }^{2-}$ deposition will be lower than projected increases in oil production owing to the use of emissions controls and export of oil outside of the region for further processing, and that base cation deposition will not change because of a shift to in-situ extraction techniques and an increasing proportion of paved roads in the region in the future.

\subsection{Model calibration}

The terrestrial areas of the study catchments are dominated by peatlands, and while surficial coverage of upland areas are relatively small, mineral deposits in the catchments are deep, and large (groundwater) sources of base cations to the lakes are present. In a traditional model application, base cation weathering rates are typically estimated (calibrated) from observed lake concentrations, yielding a catchment-based weathering estimate. In the study catchments where base cation sources predominantly originate outside of the rooting zone use of this approach would vastly overestimate contribution from these soils and preclude calibration to observed soil chemistry. Under the current approach, the two study catchments were represented in MAGIC using one mineral soil compartment, a wetland, and a lake. The model was calibrated to mineral and organic soil exchangeable base cation fractions and $\mathrm{pH}$ (using PROFILE estimated weathering rates for the mineral soil compartment), and to lake ion concentrations and $\mathrm{pH}$. Available hydrology and lake chemistry data were largely restricted to annual or open-water season averages; therefore a yearly time-step was used for model calibration. Accordingly, S retention in the wetland compartment was not modelled using redox processes (monthly sequence is required). Data detailing annual lake water chemistry (2002-2007) were used to calculate long-term annual average target values; a single year was used for the calibration owing to substantial 
Tab. 2. Site-specific fixed inputs, default parameters and calibrated parameters for each compartment (soil, wetland, lake) at the two study catchments. ${ }^{\text {a) }}$ : Calibrated parameters; ${ }^{\text {b)}}$ : default parameters; all other parameters measured.

\begin{tabular}{|c|c|c|c|c|c|c|c|}
\hline \multirow[t]{2}{*}{ Parameter } & \multirow[t]{2}{*}{ Unit } & \multicolumn{3}{|c|}{ NE07 } & \multicolumn{3}{|c|}{ SM08 } \\
\hline & & Soil & Wetland & Lake & Soil & Wetland & Lake \\
\hline Soil depth & $\mathrm{m}$ & 0.74 & $0.25^{\mathrm{b})}$ & - & 0.65 & $0.25^{\text {b) }}$ & - \\
\hline Porosity & $\%$ & 20 & $80^{\mathrm{b})}$ & - & 36 & $80^{\mathrm{b})}$ & - \\
\hline Bulk density & $\mathrm{kg} \mathrm{m}^{-3}$ & 1693 & $173^{\mathrm{b})}$ & - & 1371 & $173^{\mathrm{b})}$ & - \\
\hline Cation exchange capacity & meq kg-1 & 71 & 939 & - & 176 & 967 & - \\
\hline Initial exchangeable $\mathrm{Ca}^{\text {a) }}$ & $\%$ & 24.6 & 7.0 & - & 17.7 & 5.7 & - \\
\hline Initial exchangeable $\mathrm{Mg}^{\mathrm{a}}$ ) & $\%$ & 11.9 & 5.6 & - & 11.7 & 4.8 & - \\
\hline Initial exchangeable $\mathrm{Na}^{\text {a) }}$ & $\%$ & 2.2 & 1.7 & - & 1 & 1.7 & - \\
\hline Initial exchangeable $\mathrm{K}^{\mathrm{a})}$ & $\%$ & 1.5 & 8.9 & - & 1.9 & 9.4 & - \\
\hline Temperature & ${ }^{\circ} \mathrm{C}$ & 3.6 & $5.0^{\mathrm{b})}$ & $5.0^{\mathrm{b})}$ & 3.2 & $5.0^{\mathrm{b})}$ & $5.0^{\mathrm{b})}$ \\
\hline Dissolved organic carbon & $\mu \mathrm{mol} \mathrm{L}-1$ & $70^{\mathrm{b})}$ & $350^{\mathrm{b})}$ & $197^{\text {a) }}$ & $70^{\mathrm{b})}$ & $275^{\mathrm{b})}$ & $71^{\text {a) }}$ \\
\hline Partial pressure of $\mathrm{CO}_{2}{ }^{\mathrm{b})}$ & $\operatorname{atm}(\mathrm{x} 100)$ & 0.4 & 0.038 & 0.038 & 0.4 & 0.038 & 0.038 \\
\hline Aluminium solubility coefficient ${ }^{\text {b) }}$ & $\log$ & 9.5 & 7.5 & 7.5 & 9.5 & 7.5 & 7.5 \\
\hline $\mathrm{SO}_{4}^{2-}$ adsorption half saturation ${ }^{\mathrm{b})}$ & $\mu e q \mathrm{~L}^{-1}$ & 500 & - & - & 500 & - & - \\
\hline $\mathrm{SO}_{4}{ }^{2-}$ adsorption max. capacity ${ }^{\mathrm{b})}$ & meq $\mathrm{kg}^{-1}$ & 7.5 & - & - & 7.5 & - & - \\
\hline S sedimentation rate ${ }^{b)}$ & $\mathrm{m} \mathrm{y}^{-1}$ & - & - & 0.6 & - & - & 0.6 \\
\hline $\mathrm{Ca}^{2+}$ weathering ${ }^{\text {a) }}$ & meq $\mathrm{m}^{-2}$ & 6.4 & - & - & 5.4 & - & - \\
\hline $\mathrm{Mg}^{2+}$ weathering ${ }^{\mathrm{a})}$ & meq $\mathrm{m}^{-2}$ & 1.6 & - & - & 1.9 & - & - \\
\hline $\mathrm{Na}^{+}$weathering ${ }^{\mathrm{a})}$ & $\mathrm{meq} \mathrm{m}^{-2}$ & 3.6 & - & - & 4.5 & - & - \\
\hline $\mathrm{K}^{+}$weathering ${ }^{\mathrm{a})}$ & meq $\mathrm{m}^{-2}$ & 9.5 & - & - & 7.5 & - & - \\
\hline $\mathrm{Ca}^{2+}$ source ${ }^{\mathrm{a})}$ & meq $\mathrm{m}^{-2}$ & - & 27.4 & 27.4 & - & - & 8.0 \\
\hline $\mathrm{Mg}^{2+}$ source $^{\mathrm{a})}$ & meq $\mathrm{m}^{-2}$ & - & 14.8 & 14.8 & - & - & 6.4 \\
\hline $\mathrm{Na}^{+}$source $^{\mathrm{a})}$ & meq $\mathrm{m}^{-2}$ & - & 3.6 & 3.6 & - & - & 6.7 \\
\hline $\mathrm{K}^{+} \sin ^{\mathrm{a})}$ & meq $\mathrm{m}^{-2}$ & - & 2.1 & - & - & 2.1 & - \\
\hline $\mathrm{Cl}^{-} \sin \mathrm{k}^{\mathrm{a})}$ & meq $\mathrm{m}^{-2}$ & - & 0.81 & - & - & 0.82 & - \\
\hline $\mathrm{SO}_{4}^{2-} \sin \mathrm{k}^{\mathrm{a})}$ & $\%$ & - & 95 & - & - & 96 & - \\
\hline $\mathrm{NO}_{3}{ }^{-} \sin \mathrm{k}^{\mathrm{a})}$ & $\%$ & 100 & 98 & 93 & 100 & 100 & 98 \\
\hline $\mathrm{NH}_{4}^{+} \sin \mathrm{k}^{\mathrm{a})}$ & $\%$ & 100 & 76 & 92 & 100 & 85 & 91 \\
\hline
\end{tabular}

variation in annual lake chemistry and a relatively short observation period with no clear trends. The target year used for the manual iterative calibration was 2005 (year of soil sampling and the mid-point of lake observations).

For a select number of model parameters, catchment specific data were not available, and default values were used for the two study catchments. In the mineral soil compartment, the aluminium solubility constant (KAl) was set according to conditions typical for sandy soils while $\mathrm{pCO}_{2}$ was approximated from Kopacek et al. (2004) (Tab. 2). These default parameters were considered appropriate as use of these values resulted in comparable simulated and observed soil solution $\mathrm{SO}_{4}{ }^{2-}$ concentrations. Forests in the catchments are mature and free of harvesting influences and no nutrient uptake was specified for the soil compartments. Flow routing of water from mineral soil to the lake was set according to estimates of groundwater discharge to the lakes (J.J. Gibson, pers. comm.). In effect, the majority $(>75 \%)$ of percolating water from forest soils passed directly to the lake and the remainder routed through the peatland enroute to the lake. This is consistent with present understanding of the hydrology in the catchments whereby groundwater flow to the lakes originates locally (within the catchment). The wetland compartment was calibrated with the understanding that surficial runoff through the acrotelm is generated primarily when water table height is raised, and that this active layer strongly influences lake water chemistry.
Accordingly, organic soil was represented using a default soil depth set equal to the observed range in water level fluctuation $(0.25 \mathrm{~m}$ : K. Tattrie, pers. comm.). Organic soil bulk density followed Zoltai \& Vitt (1995), while temperature was estimated from annual air temperature, partial pressure of carbon dioxide $\left(\mathrm{pCO}_{2}\right)$ was set to atmospheric concentrations, and $\mathrm{KAl}$ set equal to the value used by Aherne et al. (2006) (Tab. 2). Default parameter values for $\mathrm{KAl}$ and $\mathrm{pCO}_{2}$ in the lake compartment were equivalent to those in the wetland, and a S sedimentation velocity in the lake (0.6 $\mathrm{m} \mathrm{y}^{-1}$ : Kelly et al. 1987) was also used (Tab. 2). For the remaining input parameters (Tab. 2), a lumped average for each compartment was calculated from data collected at the catchment (site-specific fixed inputs) or calibrated as described below.

After initial parameterization of the model to reflect the conditions in the catchments (described above), a series of sequential steps was used to calibrate the model, first to observed soil chemistry and subsequently to lake chemistry. Each step throughout the calibration procedure was executed repeatedly in order to generate the best possible fit between simulated and target values prior to proceeding to the next step.

\subsubsection{Calibration to soil chemistry}

Weathering rate estimates for multiple $(n=3)$ pits in each catchment were generated with PROFILE (Warfvinge \& Sverdrup 1992). PROFILE is a steady-state soil chemical model with a weathering rate sub-model 
Tab. 3. Model simulated (1900, 2035, 2100) and average observed (2005) lake $\mathrm{pH}$ and ion concentrations, and soil and wetland exchangeable fractions used as targets during calibration at NE07 and SM08 under the double acid forecast scenario. Relative error between model simulated value and 2005 target value for each parameter is presented.

\begin{tabular}{|c|c|c|c|c|c|c|c|c|c|c|c|}
\hline \multirow[b]{2}{*}{ Parameter } & \multirow[b]{2}{*}{ Units } & \multicolumn{5}{|c|}{ NE07 } & \multicolumn{5}{|c|}{ SM08 } \\
\hline & & 1900 & 2005 & 2035 & 2100 & $\%$ error & 1900 & 2005 & 2035 & 2100 & $\%$ error \\
\hline $\mathrm{pH}$ & & 5.2 & 5.2 & 5.2 & 5.2 & 0.11 & 5.2 & 5.1 & 4.8 & 5.0 & -0.07 \\
\hline $\mathrm{Ca}^{2+}$ & $\mu$ eq $L^{-1}$ & 158.5 & 166.3 & 172.9 & 184.2 & 0.05 & 39.9 & 57.4 & 64.8 & 77.7 & -0.21 \\
\hline $\mathrm{Mg}^{2+}$ & $\mu e q L^{-1}$ & 80.6 & 79.8 & 78.8 & 77.5 & 0.18 & 22.0 & 25.3 & 27.5 & 31.6 & 0.04 \\
\hline $\mathrm{Na}^{+}$ & $\mu$ eq $L^{-1}$ & 26.2 & 28.0 & 29.7 & 32.5 & 0.15 & 22.1 & 27.0 & 28.6 & 30.8 & -0.15 \\
\hline $\mathrm{K}^{+}$ & $\mu$ eq $\mathrm{L}^{-1}$ & 4.0 & 4.4 & 4.8 & 4.9 & 0.73 & 8.8 & 10.6 & 12.5 & 14.3 & -0.40 \\
\hline $\mathrm{NH}_{4}^{+}$ & $\mu$ eq L ${ }^{-1}$ & 0.0 & 1.5 & 3.2 & 3.2 & -4.30 & 0.1 & 2.0 & 3.4 & 3.4 & -2.27 \\
\hline $\mathrm{SO}_{4}{ }^{2-}$ & $\mu$ eq $\mathrm{L}^{-1}$ & 1.4 & 13.3 & 25.3 & 30.8 & -0.83 & 5.1 & 30.5 & 60.7 & 70.0 & 0.11 \\
\hline $\mathrm{Cl}^{-}$ & $\mu e q L^{-1}$ & 0.5 & 4.6 & 4.8 & 4.8 & 0.19 & 1.8 & 5.2 & 5.8 & 5.8 & 0.65 \\
\hline $\mathrm{NO}_{3}^{-}$ & $\mu$ eq $L^{-1}$ & 0.0 & 0.5 & 1.0 & 1.0 & 3.94 & 0.0 & 0.2 & 0.5 & 0.5 & 32.6 \\
\hline Soil eCa & $\%$ & 24.7 & 24.8 & 24.9 & 24.5 & 0.30 & 17.7 & 17.7 & 17.8 & 17.5 & 0.09 \\
\hline Soil eMg & $\%$ & 11.9 & 11.9 & 11.8 & 11.6 & -0.09 & 11.7 & 11.7 & 11.7 & 11.5 & -0.30 \\
\hline Soil eNa & $\%$ & 2.2 & 2.2 & 2.3 & 2.2 & 0.25 & 1.0 & 1.0 & 1.0 & 0.9 & 5.00 \\
\hline Soil eK & $\%$ & 1.4 & 1.4 & 1.3 & 1.1 & 0.31 & 1.9 & 1.9 & 1.8 & 1.7 & -1.95 \\
\hline Wetland eCa & $\%$ & 7.0 & 7.5 & 8.0 & 9.3 & -0.08 & 5.7 & 6.1 & 6.6 & 7.7 & -0.16 \\
\hline Wetland eMg & $\%$ & 5.6 & 5.7 & 5.8 & 6.2 & -0.41 & 4.8 & 4.9 & 4.9 & 5.1 & -0.23 \\
\hline Wetland eNa & $\%$ & 1.7 & 1.8 & 2.0 & 2.2 & 3.73 & 1.7 & 1.8 & 1.9 & 2.2 & 2.22 \\
\hline Wetland eK & $\%$ & 8.9 & 8.9 & 8.9 & 9.1 & -0.38 & 9.4 & 9.0 & 8.9 & 8.6 & -1.27 \\
\hline
\end{tabular}

that calculates the release of each base cation from the soil minerals based on climate data, soil mineralogy, and soil physical and chemical properties. PROFILE estimates were shown to be comparable to other methods for estimating weathering rates of acid-sensitive soils in the AOSR (Whitfield et al. 2010, this issue), consistent with the conclusions from soil profile-based weathering rate method comparisons in other regions (Nova Scotia: Whitfield et al. 2006a; Finland: Starr et al. 1998). Weathering rates for each base cation were adjusted within the estimated range such that the selectivity coefficients for aluminium-Ca and aluminium- $\mathrm{Mg}$ followed expectations for sandy soils (Posch et al. 2003). In the wetland compartment, DOC concentration was adjusted in order to approximate simulated and observed surface water $\mathrm{pH}$. Initial exchangeable base cation saturation for the soil and wetland compartments was subsequently set such that 2005 simulated and target base saturations were in agreement.

\subsubsection{Calibration to lake}

In the study catchments $\mathrm{N}$ cycling is not well understood and $\mathrm{N}$ dynamics were not modelled explicitly. Instead, $\mathrm{N}$ retention $\left(\mathrm{NH}_{4}{ }^{+}\right.$and $\mathrm{NO}_{3}{ }^{-}$uptake) in each compartment were adjusted in order to quantitatively match simulated lake $\mathrm{NO}_{3}^{-}$and $\mathrm{NH}_{4}{ }^{+}$concentrations with observed (target) values. Next, a wetland $\mathrm{Cl}^{-}$sink was specified in order to balance catchment input and export; biogeochemical cycling of $\mathrm{Cl}^{-}$is described in detail by Lovett et al. (2005). Lake $\mathrm{SO}_{4}{ }^{2-}$ concentrations were calibrated by specifying retention in the wetland as a percentage of inputs. Following this, lake and wetland sources (or sinks) of $\mathrm{Ca}^{2+}, \mathrm{Mg}^{2+}, \mathrm{Na}^{+}$and $\mathrm{K}^{+}$were implemented in order to match simulated and observed lake base cation concentrations. As the final step in the calibration procedure, simulated lake $\mathrm{pH}$ was matched to observed $\mathrm{pH}$ by adjusting the DOC content in the lake compartment. Calibration of $\mathrm{pH}$ by adjustment of the DOC concentration was favoured over $\mathrm{pCO}_{2}$ in this application because observed $\mathrm{pCO}_{2}$ in surface waters in this region exhibits a poor relationship with $\mathrm{pH}$ (Whitfield et al. 2009a). Following calibration of lake $\mathrm{pH}$, the series of steps in the calibration procedure described here was repeated and the calibrated parameters refined until no further improvements could be made between observed and target values for soils and surface waters.

\section{RESULTS AND DISCUSSION}

\subsection{Calibration}

Model calibrations to soil and wetland exchangeable base cation fractions yielded good agreement between simulated and observed (target) values (Tab. 3). Relative error for these targets was generally below $1 \%$ except for the exchangeable $\mathrm{Na}^{+}$fractions, which had much lower absolute target values and relative error as high as $5 \%$. Calibrations to lake chemistry also produced a close match between simulated and target values for all parameters (Tab. 3). Retention of $\mathrm{N}$ in these fen-dominated systems is expected (e.g., Prepas et al. 2001). Large sinks of $\mathrm{NO}_{3}{ }^{-}$and high nitrification rates in the three compartments were used to match inorganic $\mathrm{N}$ concentrations in the lake. While $\mathrm{NO}_{3}{ }^{-}$is strongly retained in these catchments, the net retention of $\mathrm{N}$ is lower, as considerable amounts of dissolved organic $\mathrm{N}$ are exported from the catchments (Whitfield 2009). The calibration procedure for $\mathrm{N}$ was coarser than for other variables (somewhat high relative error), but as observed lake inorganic $\mathrm{N}$ concentrations were low absolute differences between simulated and observed values were small. Vile et al. (2003) demonstrated a large capacity for $\mathrm{S}$ reduction in peatlands in low $\mathrm{S}$ deposition environments in Alberta, and it is not unex- 
pected that the majority of atmospherically deposited $\mathrm{S}$ received by peatlands is retained through assimilatory and dissimilatory processes. The sinks calibrated for $\mathrm{S}$ (95 and $96 \%$ of atmospheric input) and $\mathrm{Cl}^{-}$(0.81 and $0.82 \mathrm{meq} \mathrm{m}^{-2}$ ) retention at the two study catchments are consistent with mass balance calculations for the catchments (Whitfield 2009) and showed very strong agreement (Tab. 2), suggesting that the retention processes are well represented.

Weathering rates for upland soils at NE07 and SM08 are similar and low in comparison with other acid-sensitive soils in Canada (e.g., Whitfield et al. 2006a). For $\mathrm{Ca}^{2+}, \mathrm{Mg}^{2+}$ and $\mathrm{Na}^{+}$the calibrated weathering rates (Tab. 2) were generally close to the maximum PROFILE estimated rates. Calibration of weathering rates for $\mathrm{K}^{+}$required setting the rate at a level close to the minimum estimated rate. Given that K-feldspar is responsible for a large proportion of $\mathrm{K}^{+}$weathering (Holmqvist et al. 2003) and is very sensitive to PROFILE input parameters (Hodson et al. 1996), overestimation of the PROFILE generated $\mathrm{K}^{+}$weathering rate is likely. In order to match lake concentrations, a small uniform wetland $\mathrm{K}^{+}$sink was applied at both catchments (Tab. 2) such that much of the weathering derived $\mathrm{K}^{+}$was retained and the net catchment sources were small. Retention in the wetland is not unexpected given that elemental uptake in proportion to pool size in peatlands has been shown to be highest for $\mathrm{K}^{+}$(Grigal 1991). In order to match simulated and target values for lake base cation concentrations, sources (of $\mathrm{Ca}^{2+}, \mathrm{Mg}^{2+}$ and $\mathrm{Na}^{+}$) were added to either the lake (SM08), or the lake and wetland (NE07), following observations of base cation release to these different compartments in each catchment (Whitfield 2009); these sources were constant for the duration of model simulations. The sources attributed to these areas were considerably larger than inputs from weathering, both on an areal basis (Tab. 2), and in terms of total flux, owing to a small proportion of the catchment areas occupied by mineral soils. The exact nature of these base cation sources is unknown. Weathering of soils below the rooting zone is a possible source, but given low weathering rates of mineral soils in these catchments, and the occurrence of sedimentary bedrock underlying sandy upland deposits in the region (Devito et al. 2000), groundwater inputs to the lakes are the most likely transport mechanism for base cations to the lakes. Groundwater base cation concentrations in these two catchments are high (K. Tattrie, pers. comm.); however, quantifying water flow through deeper mineral rich deposits is subject to much uncertainty and is outside the scope of this model application.

\subsection{Model simulations}

Atmospheric deposition of $\mathrm{N}, \mathrm{S}$, and base cations is estimated to have changed during the hindcast period (Fig. 1); $\mathrm{N}$ deposition remained low until dramatic increases in the 1990s, S deposition remained low until the 1960s, increased through the 1990s, and decreased somewhat over the past decade to the 2005 level following introduction of S emission controls, while base cations increased steadily over the last half of the twentieth century. Forest soil base saturation (BS) has shown little response to changes in atmospheric deposition, with a marginal increase $(0.1 \%)$ simulated at NE07, and no change predicted for SM08 during the hindcast period (Tab. 3). In other acid-sensitive regions, an acidification induced release of base cations from the soil exchange complex has been reported (e.g., Larssen 2005). Model simulations of the exchange complex of organic soils in the peatlands suggests that these soils have responded to the higher surface water base cation concentrations resulting from elevated deposition by binding more cations. Even so, predicted BS increases in wetland soils of $0.7 \%$ (NE07) and $0.2 \%$ (SM08) were small. Only small changes in BS are expected in the future under the double acid scenario (Tab. 3). Simulated decreases in molar base cation $\left(\mathrm{Ca}^{2+}, \mathrm{Mg}^{2+}, \mathrm{Na}^{+}\right.$, $\mathrm{K}^{+}$) to aluminium ratio (BC:Al) under future conditions of higher acid deposition are expected to be more pronounced; however, at these study sites the level is predicted to remain well above the critical chemical limit for $\mathrm{Bc}: \mathrm{Al}$ (where $\mathrm{Bc}$ is $\mathrm{Ca}^{2+}, \mathrm{Mg}^{2+}$ and $\mathrm{K}^{+}$) of 10 used to protect sensitive soils in eastern Canada (Ouimet et al. 2006). Model simulations of $\mathrm{BC}: \mathrm{Al}$ across a wider number of acid-sensitive sites in the AOSR showed similar patterns (Whitfield et al. 2009b).

Over the 200 year simulation period MAGIC projections suggest only small (NE07) to moderate (SM08) change in surface water chemistry at the study catchments in response to changing deposition levels (Tab. 3). Mineral soils in both study catchments are limited in spatial extent and exhibit very limited $\mathrm{SO}_{4}{ }^{2-}$ adsorption capacity (Whitfield 2009), and consequently have little impact on lake $\mathrm{SO}_{4}{ }^{2-}$ concentrations. In contrast, much of the $\mathrm{S}$ deposition to the catchments is retained in the peatlands, dampening the potential change in lake $\mathrm{SO}_{4}{ }^{2-}$ concentrations. Lake $\mathrm{SO}_{4}{ }^{2-}$ was simulated to have increased from estimated pre-industrial levels during the hindcast (1900-2005) period, coincident with rising atmospheric deposition levels, nonetheless lake concentrations are low. Sulphate concentrations are higher at SM08 and simulated increases in $\mathrm{SO}_{4}{ }^{2-}$ concentration $\left(25 \mu\right.$ eq $\left.\mathrm{L}^{-1}\right)$ have been more pronounced in this catchment. SM08 has a higher relative lake area than NE07, and proportionally more of the $\mathrm{S}$ deposition to the catchment falls directly on the lake and therefore is not subject to retention in the peatlands. In addition, the precipitation to runoff ratio and the lake retention time are higher at SM08 and $\mathrm{SO}_{4}{ }^{2-}$ concentrations can be expected to increase in the lake relative to precipitation owing to greater evaporative enrichment, although this would be at least partially offset by greater loss through sedimentation. At NE07 where the relative lake area is small, and extensive peatland coverage is responsible 
for retaining the majority of the $\mathrm{SO}_{4}{ }^{2-}$ deposited on the catchment, simulated changes in $\mathrm{SO}_{4}{ }^{2-}$ over the hindcast period were more limited $\left(12 \mu \mathrm{eq} \mathrm{L}{ }^{-1}\right)$. In $2005, \mathrm{NH}_{4}{ }^{+}$ and $\mathrm{NO}_{3}{ }^{-}$concentrations in 2005 are very low in both lakes and are estimated to have increased only marginally over background levels (Tab. 3) owing to near quantitative retention in the terrestrial catchments.

Base cation concentrations in the study lakes respond in a manner similar to $\mathrm{SO}_{4}{ }^{2-}$. Deposition of $\mathrm{K}^{+}$ is low, and increases in lake concentration were marginal, while changes were most evident for $\mathrm{Ca}^{2+}$, which dominates base cation deposition. Small increases in lake $\mathrm{Ca}^{2+}$ concentration were predicted for NE07 (8 $\mu \mathrm{eq}$ $\mathrm{L}^{-1}$ ) with somewhat greater change estimated at SM08 $\left(17 \mu\right.$ eq $\left.\mathrm{L}^{-1}\right)$. Some base cation leaching due to elevated $\mathrm{SO}_{4}{ }^{2-}$ deposition could have initially stimulated increases in lake base cation concentrations; however given that modelled soil BS at the study catchments is stable and that concentrations of $\mathrm{Ca}^{2+}$ and $\mathrm{Mg}^{2+}$ simulated for the study lakes remain elevated, the change can be more aptly attributed to changes in base cation deposition, which is estimated to have increased substantially from background levels (Fig. 1). At NE07, where mineral rich groundwater inputs represent a substantial source of base cations to the lake, modelled pre-industrial concentrations of $\mathrm{Ca}^{2+}$ and $\mathrm{Mg}^{2+}$ are high compared with SM08 (Tab. 3). While increases in base cation concentrations have been of the same magnitude, the increase is much more apparent at SM08 due to a greater relative change from background levels.

Charge balance acid neutralizing capacity and $\mathrm{pH}$ are often used as the chemical criteria to which acidsensitive biota are anticipated to respond (Dillon et al. 1987; Wright \& Cosby 2003). In the AOSR, the working group charged with developing a management plan for emissions of acid precursors has selected an $\mathrm{ANC}_{\mathrm{CB}}$ of $75 \mu \mathrm{eq} \mathrm{L}^{-1}$ as the chemical criteria for establishing critical loads that will preserve ecosystem integrity. In eastern Canada, a critical chemical limit for $\mathrm{ANC}_{\mathrm{CB}}$ ranging from $20 \mu \mathrm{eq} \mathrm{L}^{-1}$ (Whitfield et al. 2006b) to 40 $\mu$ eq $\mathrm{L}^{-1}$ (Henriksen et al. 2002) has been designated to protect acid-sensitive biota. The critical $\mathrm{ANC}_{\mathrm{CB}}$ being used in the AOSR appears to be more stringent, and was selected using a precautionary approach; however correcting $\mathrm{ANC}_{\mathrm{CB}}$ of high $\mathrm{DOC}$ lakes in the northern $\mathrm{Al}-$ berta for the influence of organic carbon (e.g., Lydersen et al. 2004) suggests that the critical threshold for $\mathrm{ANC}_{\mathrm{CB}}$ limit of $75 \mu \mathrm{eq} \mathrm{L}^{-1}$ is consistent with the levels used in eastern Canada. Nevertheless, it is not known whether acid-sensitive aquatic organisms will respond at this higher $\mathrm{ANC}_{\mathrm{CB}}$ level. Assessments of benthic macroinvertebrates in lakes across the region suggest that these organisms respond to lake $\mathrm{pH}$ and DOC concentrations rather than to $\mathrm{ANC}_{\mathrm{CB}}$ (Parsons et al. 2010, this issue), possibly an artefact of the high base cation concentrations observed in surface waters of the region.
At the study lakes, $\mathrm{ANC}_{\mathrm{CB}}$ values are high, and given that only a small proportion of $\mathrm{SO}_{4}{ }^{2-}$ and $\mathrm{NO}_{3}{ }^{-}$ deposition to the catchments is received in the lakes, it is not surprising that there has been little change in $\mathrm{ANC}_{\mathrm{CB}}$ over the course of the hindcast period. In fact, measured intra-year variability in $\mathrm{ANC}_{\mathrm{CB}}$ at $\mathrm{NE} 07$ is greater than the simulated change (Fig. 2).

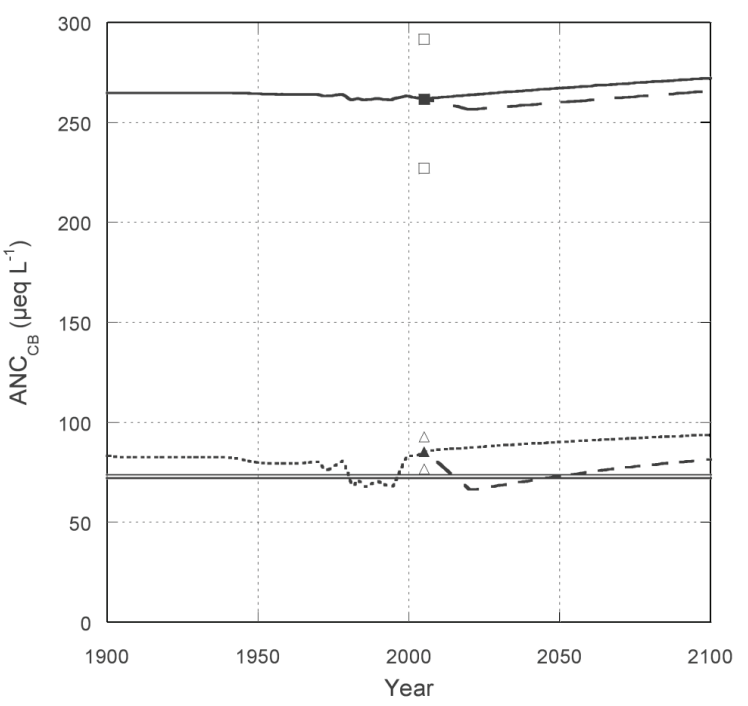

Fig. 2. MAGIC simulated charge balance acid neutralizing capacity $\left(\mathrm{ANC}_{\mathrm{CB}}\right)$ at $\mathrm{SM} 08$ and $\mathrm{NE07,} \mathrm{with} \mathrm{base} \mathrm{case} \mathrm{(SM08:}$ dotted, NE07: solid) and double acid (SM08: short dash, NE07: long dash) forecast simulations. Triangles (SM08) and squares (NE07) represent mean (solid) and quartiles (open) of measured $\mathrm{ANC}_{\mathrm{CB}}$ in the study lakes, with critical threshold $\mathrm{ANC}_{\mathrm{CB}}$ indicated by solid double horizontal line.

Paleolimnological reconstructions of lake chemistry at NE07 suggest that $\mathrm{pH}$ has been depressed in recent decades (Curtis et al. 2010, this issue). Given that the model simulations presented here indicate little acidification of this lake due to elevated atmospheric deposition of inorganic acids, another mechanism (e.g., organic acid production) is more likely responsible for this change. Simulated lake $\mathrm{ANC}_{\mathrm{CB}}$ is more variable at SM08 (Fig. 2). Estimated pre-industrial and current $\mathrm{ANC}_{\mathrm{CB}}$ at $\mathrm{SM} 08$ are above the critical threshold of 75 $\mu$ eq $\mathrm{L}^{-1}$; however hindcast simulations indicate that $\mathrm{ANC}_{\mathrm{CB}}$ was depressed below this threshold during the 1980 s and 1990s, coinciding with the period of highest $\mathrm{SO}_{4}{ }^{2-}$ deposition. Forecast simulations for this catchment suggest that $\mathrm{ANC}_{\mathrm{CB}}$ will experience little change under the base case scenario, with small increases over modelled historical condition attributed to future $\mathrm{BC}$ deposition being higher than the historical level. For the double acid scenario, $\mathrm{ANC}_{\mathrm{CB}}$ is predicted to decrease as $\mathrm{SO}_{4}{ }^{2-}$ deposition increases over the next two decades, before exhibiting a gradual increase as the system moves toward a new equilibrium under conditions of higher acid deposition. SM08 appears to be more sensitive owing to a lower (historical) $\mathrm{ANC}_{\mathrm{CB}}$; nonetheless 


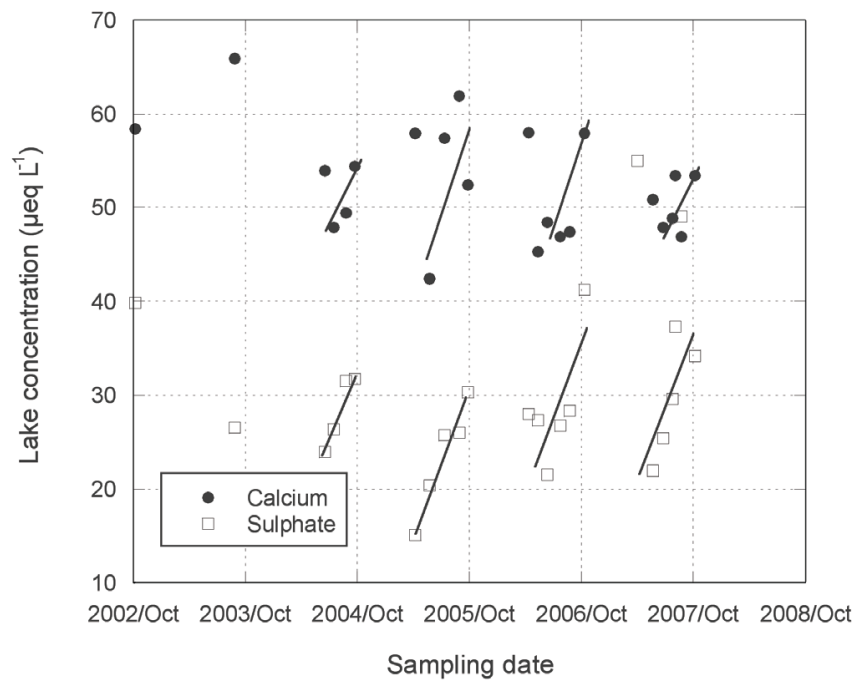

Fig. 3. Variability in lake concentrations of calcium and sulphate at SM08 during the observation period (2002-2007). Generally for these ions, concentrations increase over the open water season due to evaporative concentration (indicated with black lines).

simulated $\mathrm{ANC}_{\mathrm{CB}}$ decreases were temporary, suggesting the impacts due to acidification will be limited. These predictions contrast previous work for the region that suggested potential impacts at some lakes (Bennett et al. 2008), however this assessment considered $S$ to behave conservatively. In the current study, $\mathrm{S}$ behaviour was more completely parameterized within the model to account for catchment retention processes.

\subsection{Uncertainty and limitations}

This model application to two intensively studied catchments in the AOSR uses a detailed inventory of catchment-specific data and calibrates to observed data for all three landscape components (mineral soil, organic soil, and lake), thus it should provide a reasonable representation of catchment behaviour. There are however, uncertainties with and limitations of all model applications, and in this application, the use of longterm average data for many model parameters (hydrology, precipitation, lake chemistry) meant that it was not possible to capture interannual variability. Capturing this variability through a calibration to long-term time series of surface water chemistry has been favoured in recent applications of MAGIC in Canada (e.g., Aherne et al. 2006; Whitfield et al. 2007) as this approach is best able to simulate trends in surface water chemistry. Further, Larssen et al. (2005) demonstrated that uncertainties in future simulations are lower when calibrations use a longer time series. While trends are not evident at the study catchments, most chemical parameters show considerable year-to-year variability (e.g., Fig. 3) and open water season lake chemistry suggests that hydrology is an important influence. A concentration effect is apparent in most years, where lake concentrations are diluted following snowmelt and increase thereafter due to evaporative enrichment (Fig. 3). Additional complicating factors are that discharge may exit the catchment without influencing lake chemistry (runoff bypasses the lake due to rain on snow events or differences in timing of snowmelt and ice-out; J.J. Gibson, pers. comm.) and that atmospheric deposition is likely to vary between years owing to local extraction activity. At present there is insufficient understanding of and data available to describe these influences during model parameterization. As a result, it is not yet possible to model lake chemistry at a resolution that would allow for simulation of this variability, and calibration to a series of multi-year observations. While model simulations suggest that $\mathrm{ANC}_{\mathrm{CB}}$ will be above the critical limit for all (NE07) and most (SM08) of the simulation period; it is clear from the variability in observational data that episodic short-term depression below this limit may periodically occur at SM08. Consequently, assessing the risk of episodic depressions in $\mathrm{ANC}_{\mathrm{CB}}$ in response to future $\mathrm{S}$ deposition levels remains problematic. The model simulations presented here should be interpreted with some caution, and the potential for episodic acidification should not be discounted.

The key processes that control simulated surface water chemistry are base cation inputs, and retention of $\mathrm{N}$ and $\mathrm{S}$ on the terrestrial landscape. Some consideration of uncertainty surrounding the parameterization of these processes is warranted. Until recently, deposition levels in the AOSR have remained a key uncertainty for assessing ecosystem response to acid deposition. This has been addressed here with the use of a three year record of deposition monitoring; however some uncertainty may still be associated with the deposition sequences. Temporal changes in base cation deposition may be the least well known, but increases from background levels are much smaller than for S and N. Furthermore, many catchments in the region have large base cation sources and high $\mathrm{ANC}_{\mathrm{CB}}$, and patterns of base cation deposition have a relatively small influence 
on surface water chemistry. While it is difficult to quantify groundwater base cation inputs to the lakes, it has been well established that acid-sensitive mineral soil weathering rates are generally very low in the region (Whitfield et al. 2010, this issue), thus additional base cation sources are required for calibration to lake chemistry. The nature of these sources is unlikely to change over the relatively short geologic timescales being considered under this application.

The future role of $\mathrm{N}$ in the catchments is also somewhat uncertain, and model parameterization described $\mathrm{N}$ retention quantitatively rather than using a dynamic description. Improved understanding of $\mathrm{N}$ dynamics in these systems would allow parameterization of a critical carbon to $\mathrm{N}$ ratio at which $\mathrm{N}$ leaching is expected to occur and could improve the accuracy of model simulations. In the current model application $\mathrm{N}$ retention was assumed to be constant over time. A change in $\mathrm{N}$ retention (as a proportion of deposition) would introduce uncertainty for future simulations of lake inorganic $\mathrm{N}$ concentrations and an increase in $\mathrm{NO}_{3}{ }^{-}$leaching could result in $\mathrm{ANC}_{\mathrm{CB}}$ decreases if not accompanied by an equivalent amount of base cations. Nitrogen deposition in the study area remains low relative to more polluted regions of the world where $\mathrm{NO}_{3}{ }^{-}$leaching occurs (e.g., Europe; Wright et al. 2001), suggesting that additional $\mathrm{NO}_{3}{ }^{-}$leaching from the catchments is unlikely. Further, inorganic $\mathrm{N}$ concentrations remain low relative to longterm sources of base cations in these catchments, suggesting that changes in $\mathrm{N}$ dynamics might have very limited capacity for inducing $\mathrm{ANC}_{\mathrm{CB}}$ depression to the critical threshold.

Retention of $\mathrm{S}$ on the landscape in peatland dominated catchments has been well established. Using the six year data record, the study catchments act as net sinks of S, which is consistent with most catchments in the region where data are available. While the assumption of S retention during parameterization of the study catchments is reasonable, use of a lumped parameter approach that incorporates multi-year averages as targets for model simulations could overlook short-term $\mathrm{S}$ releases. Sulphate pulses similar to those observed in eastern Canada (e.g., Dillon et al. 1997) have not as yet been linked to drought in the study catchments; however the extent of the data record is limited and these conditions can not be discounted as a possible contributor to episodic depression of $\mathrm{ANC}_{\mathrm{CB}}$ and may account for some of the observed interannual variability. In this regard, the role of future change in climate has not been addressed in this model application. Given the northerly location of the study area, and current climate change projections of increasing temperature and changes to precipitation patterns, it is possible that future climate may influence the hydrology of these catchments and alter patterns of $\mathrm{S}$ retention. Changes in hydrology that result in drought conditions in the catchment may stimulate episodic acidification at low $\mathrm{ANC}_{\mathrm{CB}}$ lakes; elevated acidic deposition could aggravate the problem. Furthermore, peatlands are a vast store of carbon, and future changes in climate and/or hydrology that result in higher or lower DOC levels in surface waters stand to have a strong influence on surface water chemistry of these boreal catchments.

\section{CONCLUSIONS}

The study catchments are predicted to have minimal chemical response to changes in atmospheric deposition level, and appear to be at limited risk of acidification due to elevated emissions of acid precursors from the oil sands industry. Both study lakes receive large inputs of base cations from their catchments, despite low weathering rates and limited extent of mineral uplands. NE07 in particular is very well buffered, retains the majority of $\mathrm{S}$ deposition in the terrestrial catchment, and is at very low risk of impact from acid deposition. SM08 demonstrates a more clear response to changes in atmospheric deposition, largely due to catchment structure, as it has a larger relative lake area, and lower proportion of peatland coverage. Notwithstanding the lower $\mathrm{SO}_{4}{ }^{2-}$ deposition relative to other regions of North America, the patterns observed at the two study lakes suggest that only catchments with a high relative lake area, limited base cation inputs and/or limited coverage of peatlands in the terrestrial catchment will be at risk of surface water acidification.

\section{ACKNOWLEDGEMENTS}

Financial support for this work was provided through a Collaborative Research and Development Grant from the Natural Sciences and Engineering Research Council (NSERC) and the Cumulative Environmental Management Association (CEMA) awarded to JA and SAW, and a NSERC scholarship awarded to CJW. This research was undertaken, in part, thanks to funding from the Canada Research Chairs Program and an NSERC Discovery grant. The authors thank K. Tattrie and J.J. Gibson for valuable discussions during the course of this work, B. Parsons and T. Seabert for assistance with sample collection, and $\mathrm{H}$. Broadbent for assistance with laboratory analysis. The authors also gratefully acknowledge R.K. Wieder for providing the IER column data.

\section{REFERENCES}

Agriculture and Agri-Food Canada. 1998. The Canadian System of Soil Classification: Third Edition. AAFC, Ottawa, Canada.

Aherne, J., Dillon, P. J. \& B.J. Cosby. 2003. Acidification and recovery of aquatic ecosystems in south central Ontario, Canada: regional application of the MAGIC model. Hydrol. Earth Syst. Sci., 7: 561-573.

Aherne, J., M.N. Futter \& P.J. Dillon. 2008. The impacts of future climate change and sulphur emission reductions on acidification recovery at Plastic Lake, Ontario. Hydrol. Earth Syst. Sci., 12: 383-392. 
Aherne, J., T. Larssen, B.J. Cosby \& P.J. Dillon. 2006. Climate variability and forecasting surface water recovery from acidification: Modelling drought-induced sulphate release from wetlands. Sci. Tot. Environ., 365: 186-199.

Bennett, K.E., J.J. Gibson \& P.M. McEachern. 2008. Wateryield estimates for critical loadings assessment: comparisons of gauging methods versus an isotopic approach. Can. J. Fish. Aquat. Sci., 65: 83-99.

Carou, S., I. Dennis, J. Aherne, R. Ouimet, P.A. Arp, S.A. Watmough, I. Demerchant, M. Shaw, R. Vet, V. Bouchet \& M. Moran. 2008. A National Picture of Acid Deposition Critical Loads for Forest Soils in Canada. Canadian Council of Ministers of the Environment, PN 1412.

Clair, T. A., I.F. Dennis \& B.J. Cosby. 2003. Probable changes in lake chemistry in Canada's Atlantic Provinces under proposed North American emission reductions. Hydrol. Earth Syst. Sci., 7: 574-583.

Cosby, B.J. \& R.F. Wright. 1998. Modelling regional response of lakewater chemistry to changes in acidic deposition: the MAGIC model applied to lake surveys in southernmost Norway 1974-1986-1995. Hydrol. Earth Syst. Sci., 2: $563-576$

Cosby, B.J., G.M. Hornberger, J.N. Galloway \& R.F. Wright. 1985. Modeling the effects of acid deposition: assessment of a lumped parameter model of soil water and streamwater chemistry. Water Resour. Res., 21: 51-63.

Cosby, B.J., R.C. Ferrier, A. Jenkins \& R.F. Wright. 2001. Modelling the effects of acid deposition: refinements, adjustments and inclusion of nitrogen dynamics in the MAGIC model. Hydrol. Earth Syst. Sci., 5: 499-517.

Curtis, C., R. Flower, N. Rose, J. Shilland, G. Simpson, S. Turner, H. Yang \& S. Pla. 2010. Palaeolimnological assessment of lake acidification and environmental change in the Athabasca Oil Sands Region, Alberta. J. Limnol., 69(Suppl. 1): 92-104. DOI: 10.3274/JL10-69-S1-10.

De Vos, B., M. Van Meirvenne, P. Quataert, J. Deckers \& B. Muys. 2005. Predictive quality of pedotransfer functions for estimating bulk density of forest soils. Soil Sci. Soc. Am. J., 69: 500-510.

Devito, K.J., I. F. Creed, R.L. Rothwell \& E.E. Prepas. 2000. Landscape controls on phosphorous loading to boreal lakes: implications for the potential impacts of forest harvesting. Can. J. Fish. Aquat. Sci., 57: 1977-1984.

Dillon, P.J., R.A. Reid \& E. de Grosbois. 1987. The rate of acidification of aquatic ecosystems in Ontario, Canada. Nature, 329: 45-48.

Dillon, P.J., L.A. Molot \& M.N. Futter. 1997. The effect of El Nino-related drought on the recovery of acidified lakes. Environ. Monit. Assess., 46: 105-111.

Environment Canada. 2009. National climate data and information archive. Available at: http://climate.weatheroffice. ec.gc.ca/climateData/canada_e.html (verified January 28, 2009), Meteorological Service of Canada, Environment Canada, Downsview, ON.

Fenn, M.E. \& M.A. Poth. 2004. Monitoring nitrogen deposition in throughfall using ion exchange resin columns: a field test in the San Bernardino Mountains. J. Environ. Qual., 33: 2007-2014.

Galloway, J.N. 1995. Acid deposition: perspectives in time and space. Water Air Soil Pollut., 85: 15-24.

Golder Associates. 2003. Evaluation of historic and future acid deposition effects on soils in the Athabasca oil sands region. Final report submitted to $\mathrm{NO}_{\mathrm{x}}-\mathrm{SO}_{\mathrm{x}}$ Management Working Group, September, 2003.

Grigal, D.F. 1991. Elemental dynamics in forested bogs in northern Minnesota. Can. J. Bot., 69: 539-546.

Hedin, L., L. Granat, G.E. Likens, T.A. Buishand, J.N. Galloway, T.J. Butler \& H. Rodhe. 1994. Steep declines in atmospheric base cations in regions of Europe and North America. Nature, 367: 351-354.
Helliwell, R.C., R.C. Ferrier, C.D. Evans \& A. Jenkins. 1998. A comparison of methods for estimating soil characteristics in regional acidification models; an application of the MAGIC model to Scotland. Hydrol. Earth Syst. Sci., 2: 509-520.

Henriksen, A., P.J. Dillon \& J. Aherne. 2002. Critical loads of acidity for surface waters in south-central Ontario, Canada: regional application of the Steady-State Water Chemistry (SSWC) model. Can. J. Fish. Aquat. Sci., 59: 1287-1295.

Hodson, M.E., S.J. Langan \& M.J. Wilson. 1996. A sensitivity analysis of the PROFILE model in relation to the calculation of soil weathering rates. Appl. Geochem., 11: 835-844.

Holmqvist, J., A.F. Øgaard, I. Öborn, A.C. Edwards, L. Mattsson \& H. Sverdrup. 2003. Application of the PROFILE model to estimate potassium release from mineral weathering in Northern European agricultural soils. Europ. J. Agronomy, 20: 149-163.

Holowaychuk, N. \& R.J. Fessenden. 1987. Soil sensitivity to acid deposition and the potential of soils and geology in Alberta to reduce the acidity of acidic inputs. Alberta Research Council, Terrain Sciences Department, Edmonton, Alberta.

Kelly, C.A., J.W.M. Rudd, R.H. Hesslein, D.W. Schindler, P.J. Dillon, C.T. Driscoll, S.A. Gherini \& R.E. Hecky. 1987. Prediction of biological acid neutralization in acidsensitive lakes. Biogeochem., 3: 129-140.

Kopacek, J., D.W. Hardekopf, V. Majer, P. Psenakova, E. Stuchlik \& J. Vesely 2004. Response of alpine lakes and soils to changes in acid deposition: the MAGIC model applied to the Tatra Mountain Region, Slovakia-Poland. J. Limnol., 63: 143-156.

Larssen, T., C. Brereton \& J.M. Gunn. 2003. Dynamic modelling of recovery from acidification of lakes in Killarney Park, Ontario, Canada. Ambio, 32: 244-248.

Larssen, T. 2005. Model prognoses for future acidification recovery of surface waters in Norway using long-term monitoring data. Environ. Sci. Technol., 39: 7970-7979.

Larssen, T., T. Hogasen \& B. J. Cosby. 2005. Impact of time series data on calibration and prediction uncertainty for a deterministic hydrogeochemical model. Ecol. Modell., 207: 22-33.

Lovett, G.M., G.E. Likens, D.C. Buso, C.T. Driscoll \& S.W. Bailey. 2005. The biogeochemistry of chlorine at Hubbard Brook, New Hampshire, USA. Biogeochem., 72: 191-232.

Lydersen, E., T. Larssen \& E. Fjeld. 2004. The influence of total organic carbon (TOC) on the relationship between acid neutralizing capacity (ANC) and fish status of Norwegian lakes. Sci. Tot. Environ., 326: 63-69.

Mesinger, F., G. DiMego, E. Kalnay, K. Mitchell, P. C. Shafran, W. Ebisuzaki, D. Jovic, J. Woollen, E. Rogers, E. H. Berbery, M. B. Ek, Y. Fan, R. Grumbine, W. Higgins, H. Li, Y. Lin, G. Manikin, D. Parrish \& W. Shi. 2006. North American Regional Reanalysis: A long-term, consistent, high-resolution climate dataset for the North American domain, as a major improvement upon the earlier global reanalysis datasets in both resolution and accuracy. Bull. Amer. Meteorol. Soc., 87: 343-360.

Ouimet, R., P.A. Arp, S.A. Watmough J. Aherne \& I. Demerchent. 2006. Determining and mapping critical loads of acidity and exceedances for upland forest soils in eastern Canada. Water Air Soil Pollut., 172: 57-66.

Palmer, C.J. \& D.O. Trew. 1987. The sensitivity of Alberta lakes and soils to acidic deposition - Overview Report. Water Quality Control Branch, Pollution Control Division, Alberta Environment. Edmonton, AB.

Parsons, B., S.A. Watmough, P.J. Dillon \& K.M. Somers. 2010. Relationships between lake water chemistry and benthic macroinvertebrates in the Athabasca Oil Sands Region, Alberta. J. Limnol., 69(Suppl. 1): 118-125. DOI: 10.3274/JL10-69-S1-12. 
Posch, M., J-P. Hettelingh \& J. Slootweg. 2003. Manual for dynamic modelling of soil response to atmospheric deposition. Rijksinstituut voor Volksgezondheid en Milieu, Bilthoven.

Prepas, E.E., D. Planas, J.J. Gibson, D.H. Vitt, T.D. Prowse, W.P. Dinsmore, L.A. Halsey, P.M. McEachern, S. Paquet, G.J. Scrimgeour, W.M. Tonn, C.A. Paszkowski \& K. Wolfstein. 2001. Landscape variables influencing nutrients and phytoplankton communities in Boreal Plain lakes of northern Alberta: a comparison of wetland- and uplanddominated catchments. Can. J. Fish. Aquat. Sci., 58: 1286-1299.

Starr, M., A. Lindroos, T. Tarvainen \& H. Tanskanen. 1998. Weathering rates in the Hietajarvi Integrated Monitoring catchment. Boreal Environ. Res., 3: 275-285.

Timilsina, G.R., N. LeBlanc \& T. Walden. 2005. Economic impacts of Alberta's Oil Sands. Canadian Energy Research Institute, Calgary, AB. Available at: www.ceri.ca/ Publications/documents/OilSandsReport-Final.PDF

Vet, R.J. \& M. Shaw. 2004. 1994-1998 average dry deposition velocities calculated using the MSC Air Quality Research Branch dry deposition model (RDM). Meteorological Service of Canada, Environment Canada, Toronto, ON.

Vile, M.A., S.D. Bridgham \& R.K. Wieder. 2003. Response of anaerobic carbon mineralization rates to sulfate amendments in a boreal peatland. Ecol. Appl., 13: 720-734.

Warfvinge, P. \& H. Sverdrup. 1992. Calculating critical loads of acid deposition with PROFILE - A steady-state soil chemistry model. Water Air Soil Pollut., 63: 119-143.

Whitfield, C.J. 2009. A dynamic modelling assessment of soil and lake chemical response to elevated $S$ and $N$ deposition in the Athabasca Oil Sands Region. PhD Dissertation, Trent University, Peterborough, ON.
Whitfield, C.J., J. Aherne \& S.A. Watmough. 2009a. Predicting the partial pressure of carbon dioxide in boreal lakes. Can. Water Resour. J., 34(4): 415-426.

Whitfield, C.J., J. Aherne \& S.A. Watmough. 2009b. Modelling soil acidification in the Athabasca Oil Sands Region, Alberta, Canada. Environ. Sci. Technol., 43: 5844-5850.

Whitfield, C.J., S.A. Watmough, J. Aherne \& P.J. Dillon. 2006a. A comparison of weathering rates for acid-sensitive catchments in Nova Scotia, Canada, and their impact on critical load calculations. Geoderma, 136: 899-911.

Whitfield, C.J., J. Aherne, S.A. Watmough, P.J. Dillon \& T.A. Clair. 2006b. Recovery from acidification in Nova Scotia: temporal trends and critical loads for 20 headwater lakes. Can. J. Fish. Aquat. Sci., 63: 1504-1514.

Whitfield, C.J., J. Aherne, P.J. Dillon \& S.A. Watmough. 2007. Modelling acidification, recovery and target loads for headwater catchments in Nova Scotia, Canada. Hydrol. Earth Syst. Sci., 11: 951-963.

Whitfield, C.J., J. Aherne, S.A. Watmough \& M. McDonald. 2010. Estimating the sensitivity of forest soils to acid deposition in the Athabasca Oil Sands Region, Alberta. $J$. Limnol., 69(Suppl. 1): 201-208. DOI: 10.3274/JL10-69S1-20.

Wright, R.F., C. Alewell, J.M. Cullen, C.D. Evans, A. Marchetto, F. Moldan, A. Pretchel \& M. Rogora. 2001. Trends in nitrogen deposition and leaching in acid-sensitive streams in Europe. Hydrol. Earth Syst. Sci., 5: 299-310.

Wright, R.F. \& B.J. Cosby. 2003. Future recovery of acidified lakes in southern Norway predicted by the MAGIC model. Hydrol. Earth Syst. Sci., 7: 467-483.

Zoltai, S.C. \& D.H. Vitt. 1995. Canadian wetlands: Environmental gradients and classification. Vegetatio, 118: 131137. 